\title{
Does Learners' Prior Knowledge Moderate the Detrimental Effects of Seductive Details in Reading from Text? A 2 by 3 Study
}

\author{
Zhe (Joey) Wang
}

PhD., Corresponding author, Washington State University, USA, zhe.wang2@wsu.edu

\section{Olusola Adesope}

Assoc. Prof., Washington State University, USA, olusola.adesope@wsu.edu

Previous work on seductive details has demonstrated that interesting but irrelevant messages hinder students' text learning. Considering that there is little evidence suggesting the relationship between seductive details and prior knowledge, the present study examined how seductive details affect learning in terms of prior knowledge to address the gap. Using a 2 (prior knowledge: high or low) x 3 (seductive details: not presented, presented first, and presented last) design we asked students $(N=209)$ drawn from a Chinese middle school to learn a text about the earth. The results showed that, low-prior-knowledge participants reading only base passage outperformed those reading seductive details (regardless of the placement) on both recall and problem-solving performance; High-priorknowledge participants who only read the base passage and those who read seductive details at the end outperformed those who read seductive details first on problem-solving performance. The findings indicate that prior knowledge can compensate the negative effect of seductive details conditionally. Implications for research and practice are delineated and future research directions are presented.

Key Words: seductive details, text learning, prior knowledge, recall performance, problem-solving performance

\section{INTRODUCTION}

Promoting students' interest and enjoyment is an important learning goal because it is conductive to academic success. From time to time, teachers are concerned about that their lectures are boring. In order to arouse students' interest and capture their attention, teachers may be tempted to spice up their lecture material by introducing interesting information. For instance, consider a science teacher delivering a lecture about the formation of the earth. The teacher includes details about the yellow stone super volcano besides core content to trigger students' motivation. In contrast to the tedious physical and geological processes of how the earth was created and evolved, the mysterious and shocking consequences of a possible eruption of the super volcano might be more attractive. However, these details are irrelevant to the learning objectives and may thus 
compromise students' learning process although the lecture seems more interesting in general.

\section{REVIEW OF LITERATURE}

\section{A Review of the Seductive Details Effect}

The cognitive theory of multimedia learning (CTML) advanced by Mayer (2014) presents a comprehensive framework for instructional design and learning with interactive multimedia materials. The CTML was derived from a set of multimedia principles, including the coherence principle (also known as the seductive details effect). It states that seductive details (adding irrelevant information), even when interesting, may cause distraction or impose extraneous cognitive load on students (Mayer, 2001). Seductive details can be presented in a variety of forms including written texts, images, sounds, and videos. The majority of empirical evidence from Mayer and his colleagues has suggested that seductive details hinder learning by violating the coherence of learning materials (Harp \& Mayer, 1998; Mayer, Griffith, Jurkowitz, \& Rothman, 2008; Moreno \& Mayer, 2000; Rey, 2012).

There have been different possible causes of the seductive detail effect. For example, schema interference is one of the most likely explanations for the seductive detail effect according to current literature (Harp \& Mayer, 1998; Mayer, Heiser, \& Lonn, 2001; Rowland, Skinner, Davis-Richards, Saudargas, \& Robinson, 2008). The rationale behind the schema interference hypothesis is that presenting the irrelevant information at the beginning of the learning phase should exacerbate the seductive details effect because seductive details interfere with learning by priming inappropriate schemas around which readers organize the material. In addition to the schema interference theory, the overloading working memory theory argues that seductive details impose a heavy cognitive load on learners' limited processing capacity of the working memory and thus results in a reduced effectiveness of learning. The study by Sanchez and Wiley (2006) can lend support to the theory implicitly by indicating that adding seductive illustrations to an expository text reduced the performance of an inference verification task only for learners with low working memory capacity. Park, Moreno, Seufert, and Brunken (2011) also concluded that:

The cognitive processes of selecting relevant information and organizing this information into a coherent mental model can be affected not only in a negative way by seductive details, but also in a positive way if learners have enough resources free to use this non-redundant and interesting, but irrelevant learning material. (p. 9).

\section{Seductive Details and Individual Characteristics}

In spite of a substantial body of research evidence that implies a strong and consistent support for the seductive details effect (e.g, Harp and Mayer, 1998; Lehman, Schraw, McCrudden, and Hartley, 2007), little is known about the interaction between seductive details and other variables connected to learning performance. Clark and Mayer (2008) pointed out that "we do not know about how individual characteristics of learners are related to the effectiveness of the coherence principle" (p. 151). Although cognitive load 
has been operated as a factor moderating the seductive details effect (Park, Flowerday, \& Brunken, 2015), prior knowledge has received less than adequate attention among seductive details researchers.

Students come to class with unique individual characteristics and prior knowledge is one of such that plays an enormous role in learning. As Kalyuga (2007) suggested, learner knowledge base is a single and most important cognitive characteristics that influences learning. In addition, inspired by the expertise reversal effect, which claims that "design principles that help low-knowledge learners may not help or even hinder highknowledge learners" (Kalyuga, 2005, p.325), it is necessary to take learners' prior knowledge into account when the effectiveness of instructional design involving seductive details is tested. However, most of the research was only based on learners who lack prior knowledge known as novices in the relevant domain.

\section{The Effect of Prior Knowledge}

Prior knowledge, one of the critical prerequisites for learning, is conceptualized as the learner's content knowledge relevant to the domain studied (Gurlitt \& Renkl, 2010). Its importance renders eliciting and building on students' prior knowledge a core position in contemporary learning theory (Dochy, De Rijdt, \& Dyck, 2002; Greeno, Collins, \& Resnick, 1996). Research in educational settings has indicated that what an individual knows has a tremendous impact on what he or she is able to remember and learn (e.g., Bjorklund, 1987; Weinert \& Helmke, 1998). Specifically, according to Wetzels, Kester, and van Merrienboer (2011), prior knowledge should help learners to focus their attention to the central principles and concepts included in the explanations and provide them with a framework where the newly encountered principles and concepts can be integrated. Similarly, Priebe, Keenan, and Miller (2010) suggested, part of the benefit of prior knowledge on comprehension may be because when one has topic knowledge, then the words can be identified more readily. The empirical evidence might favor the assumption that the seductive detail effect can be neutralized or at least reduced by highprior-knowledge learners in that they are quite skilful in detecting important information connected to the goal of learning while ignoring information that is irrelevant.

However, the mere availability of prior knowledge is not sufficient to achieve meaningful learning or reach higher learning outcomes until it has been retrieved and activated (Wetzels, Kester, Merrienbor, \& Broers, 2011). According to the assimilation theory of meaningful learning, the learner's ability to use their prior knowledge is critical for meaningful learning to occur (Ausubel, 1968). Further, Wetzels, Kester, Merrienbor, \& Broers' research suggested that prior knowledge activation involves the transfer of available knowledge from long-term memory to working memory. Spires and Donley (1998) suggested that learners with prior knowledge activation would perform better on delayed open-ended and multiple-choice tests. Spires and Donley also argued that students who have activated their prior knowledge would internalize this strategy and retain it over a period of time. In other words, once prior knowledge is activated, it would facilitate the learning process and its lasting effect can resist negative impact from other irrelevant factors (e.g., seductive details) for a while. 
Regardless of the potential moderation effect of prior knowledge in the relationship between seductive details and learning performance, unfortunately, there has been little research in educational settings that has directly investigated the interaction between prior knowledge and seductive details. The study by Magner, Schwonke, Aleven, Popescu, and Renkl (2014) is one of the few that investigated how seductive details influence learning performance with different levels of prior knowledge and their findings suggested that low-prior knowledge students learned significantly more in the condition without seductive details than in the condition with seductive details while the opposite result was obtained for leaners with high prior knowledge. However, given that no prior knowledge activation strategies were used in their study, the internal validity is questioned. Therefore, to address this gap in the literature, research is needed to determine whether prior knowledge can moderate the seductive details effect in a direct way.

\section{THE PRESENT STUDY}

The current research investigated whether the seductive detail effect would hold across learners with different levels of prior knowledge. Numerous studies, as mentioned above, recruited novice learners as participants. For example, Abercrombie (2013) investigated the role of seductive details in a case-based instructional method for teacher education and all of the participants lacked teaching experience. Given the paucity of research demonstrating the seductive details effect not only on expert learners but also on novice learners, it is necessary to expand the scope of research to examine the robustness of seductive details effect with a wide range of learners. According to the facilitating effects of prior knowledge (Ainsworth \& Burcham, 2007; Chiesi, Spilich, \& Voss, 1979; Hecht, Close, \& Santisi, 2003; Schneider, Grabner, \& Paetsch, 2009; Wolfe \& Goldman, 2005) and the expertise reversal effect, we predict that prior knowledge would mitigate the damaging effect of seductive details. This study is a part of a research program that investigates the effects of seductive details with students from Chinese middle schools. The overarching goal of the study was to examine the relationship between prior knowledge and seductive details. Specifically, this study clarifies the degree to which prior knowledge moderates the seductive details effect in learning.

\section{METHOD}

\section{Participants and Design}

Two hundred and nine students drawn randomly from 10 classrooms at two middle schools in Eastern China participated in this study. All the students were from eighthgrade classes. Seventy three were female and one hundred and thirty five were male and one did not indicate gender. All participants were Chinese and their ages ranged from 12 to 14 years old $(M=13.32, \mathrm{SD}=1.15)$.

A 2 (prior knowledge: high, low) $\times 3$ (seductive details: not presented, presented first, presented last) between-subjects design was used. Given that both recall and problemsolving performance were measured, multivariate analyses of variance (MANOVA) were performed. 


\section{Materials}

For each participant, the paper-and-pencil materials consisted of a participant questionnaire, a prior-knowledge-examination sheet, a prior-knowledge-activation sheet, one of three instructional booklets, and an answer sheet.

The participant questionnaire was aimed at soliciting general demographic information such as gender and age. The prior knowledge test about the earth was administered to detect differences in level of prior knowledge for the purpose of later analysis. It consisted of 11 multiple choice items with 4 answer options that measured pre-existing knowledge the participants had before they read the texts. Five items assessed participants' prior knowledge of the structure of the earth (e.g., what is the fundamental constituting material of crustal plates?) and six assessed knowledge of materials on the earth (e.g., what is the normal status of minerals?). The prior-knowledge-activation sheet contained three colourful pictures illustrating the structure of the earth and certain landforms and one colourful picture of the world map. All of the pictures were used to initiate the activation of earth-related prior knowledge.

The first instructional booklet consisted of about 1100 Chinese-character passage about the earth. Texts were relevant to the school district science requirements. The second instructional booklet contained the same base passage as in the first booklet along with approximately 500 additional characters (seductive details) at the beginning of the passage intended to make the passage more interesting. The additional characters were about the narrative description of the possible effects of an eruption of the yellow stone super volcano. The third instructional booklet included the same reading materials as the second one, except that the seductive details were presented at the end of the passage. The base texts and seductive details were comparable in content difficulty.

The recall sheet contained 15 multiple choice items with 4 answer options and the problem-solving sheet contained 3 open-ended questions. All questions were tightly associated with the base passage (not with the seductive details). For example, one of the multiple-choice items was: "Where are earthquakes likely to occur? (A. Center of a plate; B. Thin regions of plates; C. Inside of the oceans; D. Boundaries between colliding plates.)" One of the open-ended questions was: "What would happen to the soil if there were no plants and animals?"

\section{Procedure}

In the first session, all participants were asked to complete a prior knowledge test about the earth within 5 minutes. Then, in the second session, prior knowledge was activated through mobilization initiated by the prior knowledge activation pictures and words. Four pictures depicting the landforms of the earth were presented on a piece of paper and all participants were required to read the instructions following the pictures: "Bring to mind everything you know about the earth (how the earth was formed, its shape and texture, animals and plants that live on the earth, etc.). It can come from what you learn from your teachers, what you read after class, what you watch from TV, what you discuss with your parents and friends, etc." 
After collecting information about prior knowledge, participants were randomly assigned to one of three treatment groups and informed that they would be reading a text about the earth. Those in the base-passage group read the passage about the earth without seductive details; those in the seductive-details-before group read the seductive details presented at the beginning of the passage; those in the seductive-details-after group read the seductive details presented at the end of the passage.

As a matter of fact, using a time limit in the learning phase might lead to lower learning performance for learners in the seductive details condition because these learners may have trouble processing larger amounts of information or have to skip some reading materials in order to finish reading on time (Rey, 2012). In response to the issue, we used time limit in proportion to the amount of message the learner received rather than an absolute time limit for all learners. For learners who only read the base passage, they were given $15 \mathrm{~min}$ in reading; for learners in the seductive details condition, they were given $20 \mathrm{~min}$ in reading.

After the reading time had elapsed, the booklets were collected and each participant was given an answer sheet including 15 multiple-choice questions and 3 open-ended questions. They were allowed 20 minutes to complete all the questions.

\section{FINDINGS}

\section{Preliminary Analyses}

For the prior knowledge test, one point was given for each correctly answered item resulting in a possible score ranging from 0 to 11 points (Cronbach's alpha $=.85$ ). For the multiple-choice questions used to assess recall performance, one point was given for each correctly answered item yielding a possible score ranging from 0 to 15 points $($ Cronbach's alpha $=.92)$. For the open-ended questions used to assess problem-solving performance, two independent raters analyzed and scored each question from 0 to 5 points (Cronbach's alpha $=.79$ ) and the possible problem-solving score for each participant ranged from 0 to 15 . They assigned one point for each acceptable answer and reached an inter-rater reliability of $r=.85$. Those participants whose prior knowledge score was in the upper half of the overall distribution (scores $>$ or $=6.4$ ) were identified as high in prior knowledge, where those whose score was in the lower half (scores < 6.4) were identified as low in prior knowledge. Two participants' responses were excluded from the final analysis because they did not follow the instructions.

A $2 \times 3$ between-subjects multivariate analysis of variance (MANOVA) was conducted with prior knowledge (high vs. low) and seductive detail condition (no-seductive vs. seductive-details-before vs. seductive details-after) as the independent variables and free recall and problem-solving performance as the dependent variables. Using Hotelling's trace statistic (also known as Hotelling's $\mathrm{T}^{2}$ ), there was a significant main effect for prior knowledge $\left(T=.275, F(2,200)=27.531, p<.001, \eta^{2}=.216\right)$ and a significant main effect for seductive detail condition $\left(T=.219, F(4,398)=10.897, p<.001, \eta^{2}=\right.$ $.099)$. Also, the prior knowledge $\times$ seductive detail condition was significant $(T=.063$, $\left.F(4,398)=3.141, p<.05, \eta^{2}=.031\right)$. Descriptive statistics for all the six conditions are presented in Table 1. 
Table 1: Condition differences on recall and problem-solving performance

\begin{tabular}{|c|c|c|c|c|c|c|c|c|c|c|c|c|}
\hline \multirow{5}{*}{$\begin{array}{l}\text { Student } \\
\text { achievement }\end{array}$} & \multicolumn{12}{|c|}{ Condition } \\
\hline & \multicolumn{4}{|c|}{ No-seductive-detail } & \multicolumn{4}{|c|}{ Seductive-detail-before } & \multicolumn{4}{|c|}{ Seductive-details-after } \\
\hline & \multirow{2}{*}{\multicolumn{2}{|c|}{$\begin{array}{c}\begin{array}{c}\text { High } \\
\text { knowledge }\end{array} \\
\mathrm{n}=36\end{array}$}} & \multirow{2}{*}{\multicolumn{2}{|c|}{$\begin{array}{c}\begin{array}{c}\text { Low } \\
\text { knowledge }\end{array} \\
\mathrm{n}=32 \\
\end{array}$}} & \multirow{2}{*}{\multicolumn{2}{|c|}{$\begin{array}{c}\begin{array}{c}\text { High } \\
\text { knowledge }\end{array} \\
\mathrm{n}=35 \\
\end{array}$}} & \multirow{2}{*}{\multicolumn{2}{|c|}{$\begin{array}{c}\begin{array}{c}\text { Low } \\
\text { knowledge }\end{array} \\
\mathrm{n}=34 \\
\end{array}$}} & \multirow{2}{*}{\multicolumn{2}{|c|}{$\begin{array}{c}\begin{array}{c}\text { High } \\
\text { knowledge }\end{array} \\
\mathrm{n}=24\end{array}$}} & \multirow{2}{*}{\multicolumn{2}{|c|}{$\begin{array}{c}\text { Low } \\
\text { knowledge } \\
\mathrm{n}=46\end{array}$}} \\
\hline & & & & & & & & & & & & \\
\hline & $\mathrm{M}$ & SD & $\mathrm{M}$ & SD & $\mathrm{M}$ & SD & $\mathrm{M}$ & SD & $\mathrm{M}$ & SD & $\mathrm{M}$ & SD \\
\hline Recall & 10.75 & 1.42 & 9.81 & 2.18 & 9.17 & 2.2 & 8.44 & 2.38 & 9.79 & 1.84 & 8.02 & 2.12 \\
\hline $\begin{array}{l}\text { Problem } \\
\text { solving }\end{array}$ & 6.44 & 2.26 & 5.03 & 3.17 & 4.29 & 2.24 & 3.12 & 2.54 & 7.29 & 1.65 & 3.65 & 2.22 \\
\hline
\end{tabular}

\section{Recall Performance}

A $2 \times 3$ between-groups analysis of variance (ANOVA) was conducted on the recall performance and the results indicated that there was a significant main effect of prior knowledge $\left[F(1,201)=15.49, M S E=65.50, p<.001 ; \eta^{2}=.07\right]$ on recall. Also, there was a significant main effect of seductive condition $[F(2,201)=10.82, M S E=45.77, p$ $\left.<.001 ; \eta^{2}=.10\right]$ on recall. However, there was no significant interaction between prior knowledge and seductive details condition $\left[F(2,201)=1.16, M S E=4.92, p>.05 ; \eta^{2}=\right.$ .01]. Descriptive statistics are presented in Figure 1.

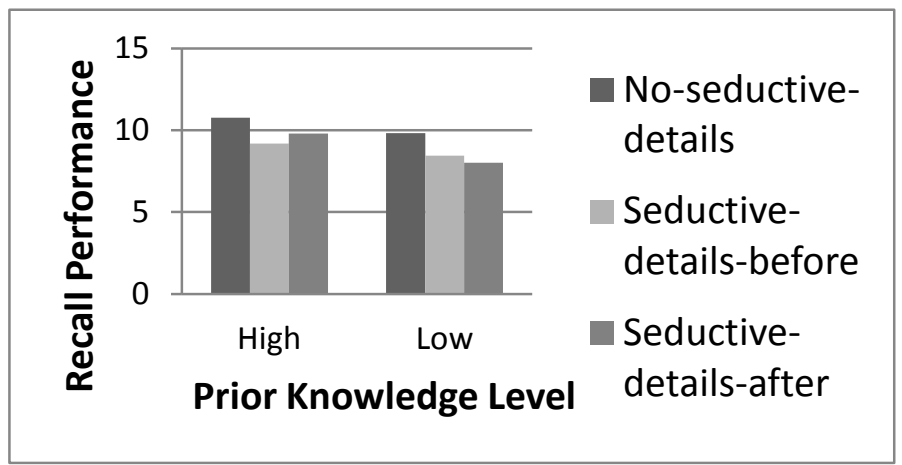

Figure 1: Recall performance by prior knowledge and seductive detail condition.

For low-prior-knowledge participants, post hoc Bonferroni test revealed that participants in the no-seductive-details $(M=9.81, S D=2.18)$ condition significantly outperformed both participants in the seductive-details-before $(M=8.44, S D=2.38)(d=.60, p<.05)$ and seductive-details-after conditions $(M=8.02, S D=2.12)(d=.83, p<.05)$ while there was no significant difference between the latter two conditions $(d=.19, p>.05)$.

For high-prior-knowledge participants, post hoc Bonferroni test revealed that participants in the no-seductive-details $(M=10.75, S D=1.42)$ condition significantly outperformed both participants in the seductive-details-before $(M=9.17, S D=2.2)(d=$ $.86, p<.05)$ and marginally outperformed seductive-details-after conditions $(M=9.79$, $S D=1.84)(d=.60, p<.07)$ while there was no significant difference between the latter two conditions $(d=-.30, p>.05)$. 


\section{Problem-solving Performance}

Another $2 \times 3$ between-groups ANOVA was conducted on the transfer performance and the results indicated that there was a significant main effect of prior knowledge $[F(1$, $\left.201)=47.528, M S E=255.648, p<.001 ; \eta^{2}=.191\right]$ on problem-solving. Also, there was a significant main effect of seductive condition $[F(2,201)=13.156, M S E=$ $\left.70.762, p<.001 ; \eta^{2}=.116\right]$ on recall. In addition, there was a significant interaction between prior knowledge and seductive details condition $[F(2,201)=5.892, M S E=$ $\left.31.693, p<.05 ; \eta^{2}=.055\right]$. Descriptive statistics are presented in Figure 2.

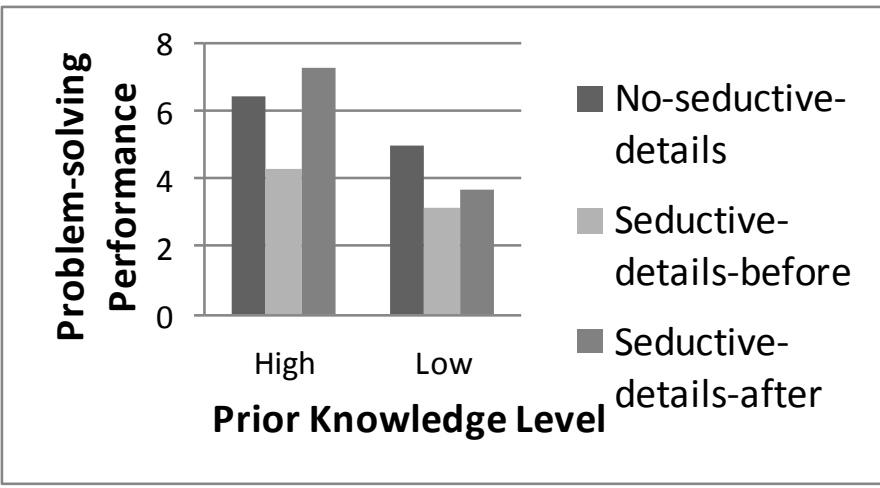

Figure 2: Problem-solving performance by prior knowledge and seductive detail condition.

For low-prior-knowledge participants, post hoc Bonferroni test revealed that participants in the no-seductive-details $(M=5.03, S D=3.17)$ condition significantly outperformed both participants in the seductive-details-before $(M=3.12, S D=2.54)(d=.67, p<.05)$ and seductive-details-after conditions $(M=3.65, S D=2.22)(d=.52, p<.05)$ while there was no significant difference between the latter two conditions $(d=-.22, p>.05)$.

For high-prior-knowledge participants, post hoc Bonferroni test revealed that participants in the no-seductive-details condition $(M=6.44, S D=2.261)$ and the seductive-details-after condition $(M=7.29, S D=1.654)$ performed on the same level $(d$ $=-.42, p>.05)$, but both significantly outperformed those in the seductive-details-before condition $(M=4.29, S D=2.24)(d=.96, d=1.48, p s<.001)$.

\section{DISCUSSION}

On free recall and problem-solving tests, learners with low prior knowledge assigned to the no-seductive-details condition outperformed those receiving seductive details regardless of the order (seductive-first or seductive-last). This result is consistent with earlier work. For example, Harp and Mayer (1998) targeted students with low knowledge of meteorology and found out that seductive details interfered with their learning of the process of lightning. This suggests that low-knowledge learners are especially vulnerable to the seductive details effect. One possible interpretation is that 
they lack necessary background knowledge or experience to guide their learning so that they would not able to integrate seductive details into their exiting mental models appropriately. Alternatively, as Rittle-Johnson, Star, and Durkin (2009) pointed out, "for novices, tasks can easily overload their working memory, as they must deal with many new elements of information at once" (p. 837). Since both the seductive details and main messages were new materials and might be conflicting with each other in the present study, it could be a challenging task for the novices to coordinate the two parts and process the entire passage in a coherent and efficient way.

However, the results for high-knowledge learners manifest a different and complicated pattern. Seductive details are deleterious in terms of retaining main ideas (recall test), which is the same as what is suggested by the results for low-knowledge learners. Nevertheless, when the learners were asked to work on problem-solving questions, those reading seductive details placed at the end of the passage achieved the same level of performance as those who only read base passage while outperforming students who read seductive details at the beginning (without seductive details $=$ seductive details first > seductive details first). It may suggest that prior knowledge plays a critical role in neutralizing the negative effect of seductive details when they are placed at the end. Specifically, prior knowledge, once activated and brought to the learning task, would benefit the learning and the positive effect could last for a while, which might resist the interference by the seductive details. The result is partly consistent with the fourth experiment of Harp and Mayer's study (1998) which found that placing the seductive details at the end of the passage resulted in students' performing as well on tests of retention and transfer as those who read the passage with no seductive details and thus suggested that the schema interference hypothesis is supported. Activated prior knowledge, however, did not help overcome the seductive details effect when seductive details were presented before the main passage. It is possible that, according to the expertise reversal effect, the cognitive conflict between prior knowledge and seductive details may cause cognitive overload.

The difference on performance demonstrated across the two measurements (recall and transfer) may be that problem-solving task reflects a deeper understanding of learning materials while retention test performance is mainly indicative of remembering facts (Bulu \& Pedersen, 2012; Nelson, Bajo, McEvoy, \& Schreiber, 1989). Specifically, how much and well detailed information can be recalled is more related to rote learning that relies primarily on the amount of information presented to learners and whether their working memory is overloaded. Learners may find themselves helpless getting rid of the distracting influence brought by seductive details regardless of how well the logical understanding has been established due to limited working memory capacity. Nevertheless, once prior knowledge stored in learners' long-term memory is activated, it can produce a tremendous facilitating effect on deeper cognitive processing during learning (Gurlitt \& Renkl, 2010). More importantly, learners' well-integrated understanding made possible by the prior knowledge can resist the interruption imposed by seductive details. 


\section{CONCLUSION}

The importance of prior knowledge for learning under different instructional conditions raises a critical instructional issue: For novices in a domain, what is the best way for students to learn new materials? One option would be to have students with low prior knowledge learn new message without presenting interesting but irrelevant information. In response, teachers and instructional designers are encouraged to focus more on building up students' prerequisite knowledge in a gradual way rather than bombard them with seductive details with the goal of motivating students. By the same token, textbook writers should construct each chapter in a well-organized and informative way that helps students establish a coherent mental representation. It is highly recommended that excessive decoration in the form of words or pictures should be avoided because too much external information may result in distraction and overwhelming situations for novices.

Another suggestion is that teachers and instructional designers may very carefully consider the placement of seductive details depending on the prior knowledge of their students. For those with high prior knowledge, teachers may conclude the class with interesting stories in order to arouse and maintain students' motivation for later phases of learning. It is noted that, however, even for those students, it might not be an optimal strategy that teachers begin a lecture with introducing entertaining material or interesting stories or jokes, which may either distract students or activate an inappropriate schema that conflicts with to-be-learned materials. Similarly, textbook writers should place interesting materials at the end of a chapter rather than the beginning if they have to be included (Rowland et al., 2008). For example, in the chapter about how the earth was formed, key knowledge facts should be presented to the student in a way that can help construct a coherent mental model; after a full understanding accomplished, entertaining information such as interesting messages on the yellow stone volcano can be included following the main content. Also, we recommend teachers and instructional designers to consider seriously which instructional strategy is appropriate when the goal of learning varies from recalling to solving problems. For example, placing seductive details at the end would hinder high-knowledge students' recall while maintain problem-solving performance.

Finally, a more direct suggestion is to desist from introducing seductive details. The present study implies that, after all, high-knowledge learners are only able to compensate the negative effects of seductive details under specific circumstances rather than profit from seductive details.

It is important in future work to explore the extent to which our results apply to multimedia learning environments, as investigating different seductive details presented in different forms may provide a way to better our understanding of the moderation effect of prior knowledge. Given the effectiveness of prior knowledge identified by the present study, future studies should continue to examine not only seductive details effect but other multimedia principles (e.g., the modality principle) with a goal of advancing the theoretical and empirical rationale for their effectiveness. 


\section{REFERENCES}

Ainsworth, S., \& Burcham, S. (2007). The impact of text coherence on learning by selfexplanation. Learning and Instruction, 17, 286-303.

Ausubel, D. P. (1968). Educational Psychology: A cognitive view. New York: Holt, Rinehart and Winston.

Bjorklund, D. F. (1987). How age changes in knowledge base contribute to the development of children's memory: An interpretive review. Developmental Review, 7, 86-92.

Bulu, S. T., \& Pedersen, S. (2012). Supporting problem-solving performance in a hypermedia learning environment: The role of students' prior knowledge and metacognitive skills. Computers in Human Behavior, 28, 1162-1169.

Chiesi, H. L., Spilich, G. J., \& Voss, J. F. (1979). Acquisition of domain-related information in relation to high and low domain knowledge. Journal of Verbal Learning and Verbal Behavior, 18, 257-273.

Clark, R. C., \& Mayer, R. E. (2008). E-learning and the science of instruction. San Francisco, CA.

Dochy, F., De Rijdt, C., \& Dyck, W. (2002). Cognitive prerequisites and learning: How far have we progressed since Bloom? Implications for educational practice and teaching. Active Learning in Higher Education, 3(3), 265-284.

Garner, R., Gillingham, M., \& White, C. (1989). Effects of "seductive details" on macroprocessing and microprocessing in adults and children. Cognition and Instruction, 6, 41-57.

Greeno, J. G., Collins, A. M., \& Resnick, L. B. (1996). Cognition and learning. In D. Berliner, \& R. Calfee (Ed.), Handbook of educational psychology. NY: Macmillan, 15-46.

Gurlitt, J., \& Renkl, A. (2010). Prior knowledge activation: how different concept mapping tasks lead to substantial differences in cognitive processes, learning outcomes, and perceived self-efficacy. Instructional Science, 38, 417-433.

Harp, S. F., \& Mayer, R. E. (1998). How seductive details do their damage: A theory of cognitive interest in science learning. Journal of Educational Psychology, 50, 414-434.

Hecht, S. A., Close, L., \& Santisi, M. (2003). Sources of individual differences in fraction skills. Journal of Experimental Child Psychology, 86, 277-302. doi:10.1016/j.jecp.2003.08.003

Kalyuga, S. (2005). Prior knowledge principle in multimedia learning. In Mayer, R. E. (Eds). The Cambridge handbook of multimedia learning (pp. 325-337). New York, NY: Cambridge University Press.

Kalyuga, S. (2007). Expertise reversal effect and its implications for learner-tailored instruction. Educational Psychology Review, 19, 509-539. 
Kalyuga, S., Chandler, P., \& Sweller, J. (1998). Levels of expertise and instructional design. Human Factors, 40, 1-17.

Kozma, R. B. (1991). Learning with media. Review of Educational Research, 61, 179-211.

Lehman, S., Schraw, McCrudden, M. T., \& Hartley, K. (2007). Processing and recall of seductive details in scientific text. Contemporary Educational Psychology, 32, 569-587.

Magner, U. I. E., Schwoke, R., Aleven, V., Popescu, O., \& Renkl, A. (2014). Triggering situational interest by decorative illustrations both fosters and hinders learning in computer-based learning environments. Learning and Instruction, 29, 141-152.

Mayer, R. E. (1999). Research-based principles for the design of instructional messages. The case of multimedia explanations. Document Design, 1, 7-20.

Mayer, R. E. (2001). Resisting the assault on science: The case for evidence-based reasoning in educational research. Educational Researcher, 30, 29-30.

Mayer. R. E., Heiser, J., \& Lonn, S. (2001). Cognitive constraints on multimedia learning: When presenting more material results in less understanding. Journal of Educational Psychology, 93, 187-198.

Mayer, R. E. (2014). Cognitive theory of multimedia Learning. In Mayer, R. E. (Eds.), The Cambridge handbook of multimedia learning (2nd ed.; pp. 43-71). New York: Cambridge University Press.

Mayer, R. E., Griffith, E., Jurkowitz, I. T. N., \& Rothman, D. (2008). Increased interestingness of extraneous details in multimedia science presentation leads to decreased learning. Journal of Experimental Psychology, 14, 329-339.

Moreno, R., \& Mayer, R. E. (2000). A coherence effect in multimedia learning: The case for minimizing irrelevant sounds in the design of multimedia instructional messages. Journal of Educational Psychology, 92, 117-125.

Nelson, D. L., Bajo, M., McEvoy, C. L., Schreiber, T. A. (1989). Prior knowledge: The effects of natural category size on memory for implicitly encoded concepts. Journal of Experimental Psychology: Learning, Memory, and Cognition, 1989, 15, 957-967.

Park, B., Moreno, R., Seufert, T., \& Brunken, R. (2011). Does cognitive load moderate the seductive details effect? A multimedia study. Computers in Human Behavior, 27, 5-10.

Priebe, S. J., Keenan, J. M., Miller, A. C. (2012). How prior knowledge affects word identification and comprehension. Reading and Writing, 25, 131-149.

Renkl, A. (1997). Learning from worked-out examples: A study on individual differences. Cognitive Sciences, 21, 1-29.

Renkl, A., \& Atkinson, R. (2003). Structuring the transition from example study to problem solving in cognitive skills acquisition: A cognitive load perspective. Educational Psychology, 38, 15-22. 
Renkl, A., Atkinson, R. K., \& Maier, U. H. (2000). From studying examples to solving problems: Fading worked-out solution steps helps learning. In L. Gleitman \& A. K. Joshi (Eds.), Proceeding of the $22^{\text {nd }}$ Annual Conference of the Cognitive Science Society (pp. 393-398). Mahwah, NJ: Erlbaum.

Rey, G. D. (2012). A review of research and a meta-analysis of the seductive detail effect. Educational Research Review, 7, 216-237.

Rittle-Johnson, B., Star, J. R., \& Durkin, K. (2009). The importance of prior knowledge when comparing examples: Influences on conceptual and procedural knowledge of equation solving. Journal of Educational Psychology, 101, 836-852.

Rowland, E., Skinner, C. H., Davis-Richards, K., Saudargas, R., Robinson, D. H. (2008). An investigation of placement and type of seductive details: The primacy effect of seductive details on text recall. Research in the Schools, 15, 80-90.

Sanchez, C. A., \& Wiley, J. (2006). An examination of the seductive details effect in terms of working memory capacity. Memory \& Cognition, 34(2), 344-355.

Schneider, M., Grabner, R. H., \& Paetsch, J. (2009). Mental number line, number line estimation, and mathematical achievement: Their interrelations in Grades 5 and 6. Journal of Educational Psychology, 101, 359-372. doi:10.1037/a0013840

Spires, H. A., \& Donley, J. (1998). Prior knowledge activation: Inducting engagement with informational texts. Journal of Educational Psychology, 90, 249-260.

Taber, K. S. (2001). The mismatch between assumed prior knowledge and the learner's conceptions: A typology of learning impediments. Educational Studies, 27(2), 159-171.

Wetzels, S. A. J., Kester, L., \& Merrienboer, J. J. G. (2011). Adapting prior knowledge activation: Mobilisation, perspective taking, and learners' prior knowledge. Computers in Human Behavior, 27, 16-21.

Weinert, F. E., \& Helmke, A. (1998). The neglected role of individual differences in theoretical models of cognitive development. Learning and Instruction, 8, 309-323. Doi: 10.1037/0022-0663.92.1.107.

Wetzels, S. A. J., Kester, L., Merrienboer, J. J. G., \& Broers, N. J. (2011). The influence of prior knowledge on the retrieval-directed function of note taking in prior knowledge activation. British Journal of Educational Psychology, 81, 274-291.

Wiley, J. (2003). Cognitive and educational implications of visually-rich media: Images and imagination. In M. Hocks \& M. Kendrick (Eds.), Eloquent images: Writing visually in new media (pp. 201-218). Cambridge, MA: MIT Press.

Wolfe, M. B. W., \& Goldman, S. R. (2005). Relations between adolescents' text processing and reasoning. Cognition \& Instruction, 23, 467-502.

Wright, P., Milroy, R., \& Lickorish, A. (1999). Static and animated graphics in learning from interactive texts. European Journal of Psychology of Education, 14(20), 203-224.

Yochum, N. (1991). Children's learning from informational text: The relationship between prior knowledge and text structure. Journal of Reading Behavior, 23, 87-108. 


\section{Turkish Abstract \\ Öğrencilerin Öncül Bilgileri Metinden Okumada Tahrik Edici Detayların Olumsuz Etkilerini Etkiliyor Mu? 2X3 Bir Çalışma}

Tahrik edicici detaylar üzerine yapılan daha önceki çalışmalar illginç ama gereksiz mesajların öğrencilerin metin öğrenmelerini engellediğini ortaya koymuştur. Tahrik edici detaylar ve öncül bilgiler arasındaki ilişkiyi gösteren çok az kanıtı dikkate alırsak, bu çalışma bu boşluğu dolduracak şekilde tahrik edici detayların öncül bilgiler bakımından öğrenmeyi nasıl etkilediğini ortaya koymaktadır. 2 (öncül bilgi: yüksek ve düşük) x 3 (Tahrik edeici detay: sunulmamış, önce sunulmuş, sonra sunulmuş) desen kullanılarak dünya hakkında bir metin öğrenen Çinli ortaokul öğrencileriyle bu çalışma yapılmıştır. Sonuçlar sadece temel metni okuyan düşük öncül bilgili katılımcıların hem geri çağırma hem de problem çözme performansında tahrik edici detayları (yer dikkate alınmayarak) okuyanlardan daha iyi olduklarını; sadece temel metni okuyan yüksek öncül bilgili katılımcılarla sonda tahrik edici detayları okuyan katılımcıların problem çözme performansında tahrik edici detayları önce okuyanlardan daha iyi olduklarını göstermiştir. Bulgular öncül bilgilerin şartlı olarak tahrik edici detayların olumsuz etkilerini telafi edebileceğini göstermiştir. Araştırma ve uygulama için göstergeler betimlenmiş ve gelecek çalışmalar için öneriler sunulmuştur.

Anahtar Kelimeler: tahrik edici detaylar, metinden öğrenme, öncül bilgiler, geri çă̆ırma performansı, problem çözme performansı

\section{French Abstract}

La connaissance Antérieure d'Apprenants Modère-t-elle les Effets Nuisibles de Détails Séduisants dans Lecture de Texte? 2 par 3 Étude

Le travail précédent sur des détails séduisants a manifesté que des messages intéressants mais sans rapport gênent l'apprentissage de texte des étudiants. Étant donné qu'il y a peu de preuve suggérant la relation entre les détails séduisants et la connaissance antérieure, l'étude présente a examiné comment l'affect de détails séduisant apprenant en termes de connaissance antérieure pour adresser l'écart. Utiliser des 2 (la connaissance antérieure: haut ou bas) x 3 (détails séduisants: non présenté, a présenté d'abord et présenté dernier) la conception nous avons demandé aux étudiants $(\mathrm{N}=209)$ dessiné d'un collège chinois d'apprendre un texte de la terre. Les résultats ont montré que, les participants de connaissance bas antérieurs lisant se basent seulement le passage a surpassé ceux qui lisent des détails séduisants (indépendamment du placement) tant sur la performance de résolution de problèmes que sur le rappel; les participants de Connaissance Haut Antérieurs qui lisent seulement le passage de base et ceux qui lisent des détails séduisants à la fin ont surpassé ceux qui lisent des détails séduisants d'abord sur la performance de résolution de problèmes. Les découvertes indiquent que la connaissance antérieure peut indemniser l'effet négatif de détails séduisants conditionnellement. Les implications pour la recherche et la pratique sont tracées et des directions de recherche futures sont présentées.

Mots Clés: des détails séduisants, l'apprentissage de texte, la connaissance antérieure, se rappellent la performance, la performance de résolution de problèmes 


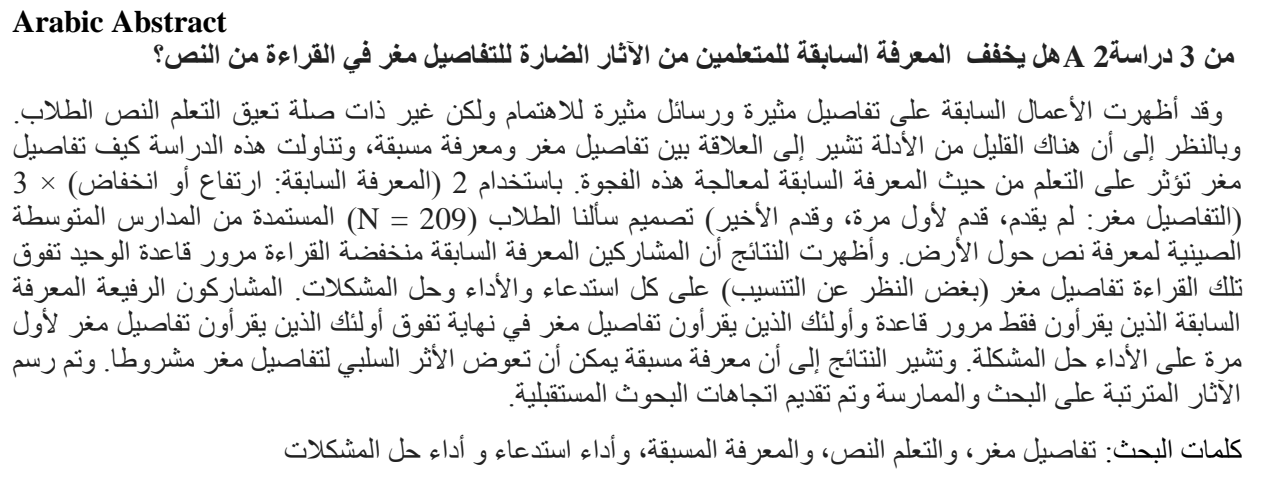

\section{German Abstract}

Hat der Lernenden Vorkenntnisse Moderieren die Schädlichen Wirkungen von Seductive Einzelheiten in von Text zu lesen? A 2 von 3-Studie

Frühere Arbeiten auf verführerische Details haben gezeigt, dass interessant, aber irrelevant Nachrichten Text Lernen der Schüler behindern. Wenn man bedenkt, dass es wenig Anzeichen dafür, dass die Beziehung zwischen verführerischen Details und Vorkenntnisse vermuten lässt, untersucht die vorliegende Studie, wie verführerische Details im Hinblick auf die Vorkenntnisse Lernen beeinflussen die Lücke zu schließen. Mit einem 2 (Vorkenntnisse: hoch oder niedrig) x 3 (verführerischen Details: nicht zuerst vorgestellt, präsentiert und vorgestellt letzte) Design, das wir Studenten $(\mathrm{N}=209)$ gefragt von einer chinesischen Mittelschule gezogen, um einen Text über die Erde zu lernen. Die Ergebnisse zeigten, dass mit niedrigem Stand der Kenntnisse Teilnehmer sowohl das Lesen nur auf Basis Passage besser als jene Lesen verführerischen Details (unabhängig von der Platzierung) Rückruf und Problemlösungs Leistung; Hoch Stand der Kenntnisse Teilnehmer, die nur die Basis Passage lesen und diejenigen, die am Ende verführerischen Details lesen übertreffen diejenigen, die zuerst auf Problemlösungs Leistung verführerischen Details lesen. Die Ergebnisse zeigen, dass vorherige Kenntnis der negative Effekt von verführerischen Details bedingt kompensieren kann. Implikationen für Forschung und Praxis werden abgegrenzt und zukünftige Forschungsrichtungen vorgestellt.

Schlüsselwörter: verführerische details, text lernen, vorwissen, erinnerungsleistung, problemlösungs leistung

\section{Malaysian Abstract}

Adakah Ilmu Sebelum Learners 'Menyederhanakan Kesan Memudaratkan Details menggoda di Reading dari teks? A 2 oleh 3 Kajian

Pekerjaan terdahulu pada seductive details telah menunjukkan bahawa mesej yang menarik tetapi tidak relevan menghalang pembelajaran teks pelajar. Memandangkan bahawa terdapat sedikit bukti mencadangkan hubungan antara seductive details dan pengetahuan terdahulu, kajian ini meneliti bagaimana seductive details menjejaskan pembelajaran dari segi pengetahuan sedia ada untuk menangani jurang. Menggunakan (pengetahuan sebelumnya: tinggi atau rendah) $2 \times 3$ (seductive details: tidak dibentangkan, yang dibentangkan pertama, dan dibentangkan terakhir) 
reka bentuk kami bertanya pelajar $(\mathrm{N}=209)$ yang diambil daripada sebuah sekolah menengah Cina belajar teks mengenai bumi. Hasil kajian menunjukkan bahawa, peserta-sebelum-ilmu rendah membaca hanya petikan asas mengatasi mereka yang membaca seductive details (tidak kira penempatan) di kedua-ingat dan prestasi penyelesaian masalah; peserta tinggi sebelumpengetahuan yang hanya membaca petikan asas dan mereka yang membaca seductive details pada akhirnya mengatasi mereka yang membaca seductive details pertama prestasi penyelesaian masalah. Dapatan kajian menunjukkan bahawa pengetahuan sedia ada boleh mengimbangi kesan negatif seductive details bersyarat. Implikasi kepada penyelidikan dan amalan yang ditandakan dan arah kajian akan datang dibentangkan.

Kata Kunci: butiran menggoda, pembelajaran teks, pengetahuan sedia ada, prestasi ingat, prestasi penyelesaian masalah 